\title{
Effect of Spironolactone on Diabetic Nephropathy Compared to the Combination of Spironolactone and Losartan
}

\author{
Atieh Makhlough ${ }^{1,2}$, Zahra Kashi $^{1, *}$, Ozra Akha ${ }^{1}$, Ehsan Zaboli ${ }^{3}$, Jamshid Yazdanicharati ${ }^{4}$ \\ ${ }^{1}$ Diabetes Research Center, Mazandaran University of Medical Sciences, Sari, IR Iran \\ ${ }_{3}^{2}$ Molecular and Cellular Biology Research Center, Mazandaran University of Medical Sciences, Sari, IR Iran \\ 3 Mazandaran University of Medical Sciences, Sari, IR Iran
${ }^{4}$ Department of Biostatistics and Epidemiology, Mazandaran University of Medical Sciences, Sari, IR Iran \\ ${ }^{*}$ Corresponding author: Zahra Kashi, Diabetes Research Center, Imam Khomeini Hospital, Mazandaran University of Medical Sciences, Razi Street, Sari, IR Iran. Tel: +98-1512261701; \\ Ext:4, Fax:+98-1512278789, E-mail: Kashi_zahra@yahoo.com.
}

Received: May 12, 2013; Revised: May 31, 2013; Accepted: June 9, 2013

\begin{abstract}
Background: Diabetic nephropathy is the most important cause of end stage renal disease (ESRD). Aldosterone is involved in renal damage through induction of fibrosis, inflammation and necrosis in the kidney tissue. Previous studies have demonstrated that the combination of angiotensin receptor blocker(ARB) and spironolactone (an anti-aldosterone drug)are efficient for albuminuria reduction. Objectives: This study was designed to evaluate the effect of spironolactone alone on diabetic nephropathy.

Patients and Methods: In this double blind randomized clinical trial, 60 type II diabetic patients with microalbuminuria were enrolled. They were divided into two groups: case group (spironolactone $25 \mathrm{mg}$ and placebo, 30 cases) and control (spironolactone $25 \mathrm{mg}$ plus losartan $25 \mathrm{mg}, 30$ cases). The treatment success rate (more than 50\% reduction in microalbuminuria) was compared between the two groups.

Results: After three months, successful treatment was seen in 70\% (95\% CI: 52 - 83) and 83.3\% (CI 95\%: 66 - 93) of case and control groups, respectively $(P=0.4)$. Mean $\pm S D$ of serum potassium levels after three months in case and control groups were $4.56 \pm 0.38$ and $4.39 \pm 0.34$ $\mathrm{mEq} / \mathrm{L}$, respectively $(\mathrm{P}=0.08)$. Mean $\pm \mathrm{SD}$ of systolic blood pressures in case and control groups were $129.67 \pm 9.4$ and $130.97 \pm 9.4 \mathrm{mmHg}$, respectively $(\mathrm{P}=0.6)$. Mean \pm SD of serum creatinine levels at the end of the study were $0.95 \pm 0.15$ in case and $0.90 \pm 0.22 \mathrm{mg} / \mathrm{dL}$ in control $\operatorname{group}(\mathrm{P}=0.4)$.

Conclusions: Spironolactone alone is as effective as the combination of spironolactone and losartan on albuminuria reduction in type 2 diabetic patients and can be used alone as an effective drug for diabetic nephropathy.
\end{abstract}

Keywords: Diabetic Nephropathy; Diabetes Mellitus, Type 2; Albuminuria; Spironolactone

\section{Background}

Diabetic nephropathy is the most significant cause of end-stage renal disease (ESRD) and the main cause of mortality and morbidity in diabetic patients. The prevalence of nephropathy in diabetes mellitus (DM) type 1 is more than DM type 2, but due to the greater number of patients presenting DM type 2, its nephropathy rate is as high as type 1 DM (1). Diabetic nephropathy is characterized by albuminuria and usually associated with hypertension, high incidence of cardiovascular morbidity and mortality and progressive renal dysfunction. The main poor prognostic factors include uncontrolled blood pressure and blood sugar, dyslipidemia and high level of proteinuria (2-4). Diabetic nephropathy finally leads to renal failure and necessitates the replacement therapy; thus, scientists are always looking forward to finding the cause of proteinuria and also solutions to slow down its progression $(1,5)$.

Urinary albumin excretion (albuminuria) is one of the important risk factors for the progression of renal disease to ESRD $(1-4,6)$. Therefore, control of microalbuminuria can slow down the progression of nephropathy (7-12). Interventional studies have demonstrated that interruption of renin-angiotensin-aldosterone system by angiotensine-converting enzyme inhibitors (ACEI) or angiotensin receptor blockers (ARB) and renin inhibitors can be extremely helpful for decelerating the progression of renal disease $(7-9,13)$; but after a while, the aldosterone level (the last product of the renin-angiotensinaldosterone system) increases to its original level due to the aldosterone escape phenomenon. This phenomenon that occurs in about $40 \%$ of patients with diabetic nephropathy, usually happens in long-term ACEIs and ARBs consumers $(12,14)$. Aldosterone acts as a renal injury mediator through inflammation induction, fibrosis and necrosis in the kidney tissue (15-17). It is assumed that aldosterone reduces the BNP7 expression, and down-

Implication for health policy/practice/research/medical education:

Diabetic nephropathy is one of the important causes of renal failure. Some patients can't use the ACEI or ARB. Our study showed that the spironolactone alone is as effective as combination of spironolactone and losartan on albuminuria reduction in type 2 diabetic patients and can be used alone as an effective drug for diabetic nephropathy.

Copyright (C) 2014, Nephrology and Urology Research Center; Published by Kowsar Corp. This is an open-access article distributed under the terms of the Creative Commons Attribution License, which permits unrestricted use, distribution, and reproduction in any medium, provided the original work is properly cited. 
regulation of BMP7 expression is one of the early events in diabetic nephropathy $(18,19)$. Therefore, it is proposed that usage of ACEIs and ARBs alone cannot prevent the aldosterone effects $(1,20)$. Some studies have reported that adjuvant therapy with aldosterone receptor blockers such as spironolactone can be effective for the albuminuria improvement $(1,12,21-23)$.

\section{Objectives}

Present study was performed to evaluate the effect of spironolactone alone compared to the combination of spironolactone and losartan on albuminuria reduction in type II diabetic patients.

\section{Patients and Methods}

This study was a double-blinded randomized clinical trial, performed in the DM health care centers of Sari, Iran from 2008 to 2011. The study was registered in IRCT (Iran) with the following registration code: IRCT 138806211241 N2. Sixty patients with type 2 diabetes mellitus, suffering from diabetic nephropathy, were enrolled in the study. The inclusion criteria were age range of 25 to 75 years, HbA1c $<9 \%$ and random urinary albumin to creatinine ratio of $20-200 \mathrm{mg} / \mathrm{gr} \mathrm{Cr}$ in two random measurements with a month interval. If only one of the two microalbumiuria tests was positive, it would be repeated the next month. Exclusion criteria were: diastolic and systolic blood pressures more than 100 and $160 \mathrm{mmHg}$, respectively; serum potassium level $>5.5 \mathrm{meq} / \mathrm{L}$; prior acute myocardial infarction (MI) or stroke during the preceding six-month period; taking proteinuria-affecting medications (corticosteroids, NSAIDs, immunosuppressant drug); renovascular disease; collagen vascular disease; obstructive uropathy; alcohol and substance abuse; pregnancy or lactation.

This study had two phases; screening and treatment. During the screening phase, patients were selected according to the inclusion criteria and then eligible patients were entered into the treatment phase. Five milliliters of fasting blood was taken for the serum creatinine, potassium, and glycosylated hemoglobin (HbA1C) assessments, and the tests were repeated 4 and 12 weeks after the intervention. Limitation of protein consumption (0.6-0.8 $\mathrm{g} / \mathrm{kg} / \mathrm{d}$ ) was advised during the study. The samples were assigned to case or control group through the RANDBETWEEN function of Microsoft Excel software. Case group comprised 30 diabetic patients who took spironolactone $25 \mathrm{mg}$ once daily plus half a tablet placebo twice a day. Control group took spironolactone $25 \mathrm{mg}$ once daily plus losartan $12.5 \mathrm{mg}$ twice a day. The intervention phase lasted for 12 weeks.

Patients' drugs consumption quality was evaluated by counting the remaining tablets at the end of each month. Albuminuria was measured in the beginning, after 4 weeks and at the end of the intervention. For these measure- ments, immunotorbidometric assay was performed by prestige 24i automated clinical chemistry analyzer (auto analyzer, Japan), using the Pars Azmon kit (Iran). Patients were visited every 4 weeks and their serum potassium levels were measured. Serum potassium level was measured by Alfa Wassermann Starlyte III electrolyte analyzer and serum creatinine was assessed by Cobas Integra 400 (Roche Diagnostics GmbH, Germany), using the Creatinine Plus kit (Roche Diagnostics GmbH, Germany).

Spironolactone dosage was reduced by half if the serum potassium level increased more than $5.5 \mathrm{mmol} / \mathrm{L}$ or systolic BP decreased less than $90 \mathrm{mmHg}$. The study was approved by the Mazandaran University of Medical Sciences Ethics Committee (Ethic code: 88-89) and informed consent was obtained from all the participants.

\subsection{Statistical Analysis}

The data were described as mean \pm SD (standard deviation). Independent sample t-test was used to compare the baseline and after intervention levels of microalbuminuria between case and control groups. Repeated measures analysis was applied for evaluation of the treatment effect as well as the trend of treatment in each group. The treatment success rate was reported as $95 \%$ confidence level. P value $<0.05$ was considered statistically significant.

\section{Results}

Twenty-three (76.7\%) of the case and $22(73.3 \%)$ of the control group were female $(\mathrm{P}=0.8)$. One patient of the case group was dropped out from the study because of not using the medications regularly. Mean age of the patients was $51.78 \pm 11.39$ years. Fifty patients (83.3\%) were under oral antidiabetic agents and 10 (16.7\%) were taking insulin. Patients under treatment with insulin were $13.3 \%$ of the case and $20 \%$ of the control group $(P=0.5)$. Table 1 shows the baseline information in two groups.

The treatment success rate (more than $50 \%$ reduction in microalbuminuria) 1 month after the intervention was $66.7 \%$ and $56.7 \%$ in the case and control groups, respectively $(\mathrm{P}=0.4)$. After 3 months, this rate was $70 \%$ in the case and $83.3 \%$ in control group $(\mathrm{P}=0.4)$ (Table 2$)$. The treatment success rate was not different between two sexes. After 4 weeks of intervention, microalbuminuria disappeared in $50 \%$ of cases and $33.3 \%$ of controls $(P=0.2)$. Sixty percent of the control and $46.7 \%$ of the case group did not have microalbuminuria at the end of the study $(\mathrm{P}=0.2)$.

There were no significant increases in the serum creatinine or potassium levels of any patient. Microalbuminuria, serum creatinine level, and systolic/diastolic blood pressures were not different between the two groups after the study (Table 3). Using the repeated measures analysis, a significant therapeutic effect was observed in both groups ( $F=7.45, P=0.009)$ but there was no significant difference between the two treatment methods regarding albuminuria reduction $(\mathrm{F}=0.12, \mathrm{P}=0.7)$ (Figure 1$)$. 
Makhlough A et al.

Table 1. Descriptive Data Before Intervention in Two Groups of Spironolacton + Losartan and Spironolacton + Placebo

\begin{tabular}{llll}
\hline Variable & $\begin{array}{l}\text { Spironolacton + Losartan, } \\
\text { Mean } \pm \text { SD }\end{array}$ & $\begin{array}{l}\text { Spironolacton + Placebo, } \\
\text { Mean } \pm \text { SD }\end{array}$ & P Value \\
\hline Age, $\mathbf{y}$ & $51.2 \pm 12.29$ & $52.3 \pm 10.61$ & 0.8 \\
\hline DM $^{\mathrm{a}}$ duration, $\mathbf{y}$ & $8.66 \pm 5.39$ & $6.33 \pm 5.19$ & 0.1 \\
\hline GFR $^{\mathrm{a}}, \mathbf{m L} / \mathbf{m i n}$ & $115.6 \pm 23.5$ & $112.5 \pm 25.6$ & 0.6 \\
\hline FBS $^{\mathrm{a}}, \mathbf{m g} / \mathbf{d L}$ & $152.63 \pm 44.43$ & $147.4 \pm 44.66$ & 0.6 \\
\hline HbA1c, $\mathbf{N o}$ (\%) & $6.93 \pm 0.86$ & $7.2 \pm 0.79$ & 0.2 \\
\hline Systolic BP, $\mathbf{m m H g}$ & $136.03 \pm 4.90$ & $132.33 \pm 11.18$ & 0.1 \\
\hline Diastolic BP, $\mathbf{m m H g}$ & $82.40 \pm 7.89$ & $80.43 \pm 6.96$ & 0.3 \\
\hline Urine albumin, $\mathbf{m g} / \mathbf{g}$ & $102.03 \pm 51.98$ & $81.11 \pm 51.9$ & 0.1 \\
\hline Potassium, $\mathbf{m e q} / \mathbf{L}$ & $4.32 \pm 0.35$ & $4.49 \pm 0.31$ & 0.05 \\
\hline
\end{tabular}

a Abbreviations: DM, diabetes mellitus; FBS, fasting blood sugar; GFR, glomerular filtration rate.

Table 2. The Treatment Success Rate in Two Groups of Spironolacton + Losartan and Spironolacton + Placebo

\begin{tabular}{|c|c|c|c|}
\hline & Spironolcton + Losartan & Spironolacton + Placebo & P Value \\
\hline \multicolumn{4}{|l|}{ Male } \\
\hline After 4 weeks & 75\% (CI 95\%: 41-93) & 71.4\% (CI 95\%: 36-92) & 0.9 \\
\hline After 12 weeks & 100\% (95\%CI: 48-100) & 85.7\% (95\%CI: 49-97) & 0.3 \\
\hline \multicolumn{4}{|l|}{ Female } \\
\hline After 4 weeks & 50\% (CI 95\%: 31-69) & $65.2 \%$ (CI 95\%: 45-81) & 0.3 \\
\hline After 12 weeks & 77.3\% (95\%CI: 57-90) & $65.2 \%$ (95\%CI: 45-81) & 0.5 \\
\hline \multicolumn{4}{|l|}{ Total } \\
\hline After 4 weeks & $56.7 \%(\mathrm{CI} 95 \%: 39-73)$ & 66.7\% (CI 95\%: 49-81) & 0.4 \\
\hline After 12 weeks & 83.3\% (95\%CI: 66-93) & $70 \%$ (95\%CI: 52-83) & 0.4 \\
\hline
\end{tabular}

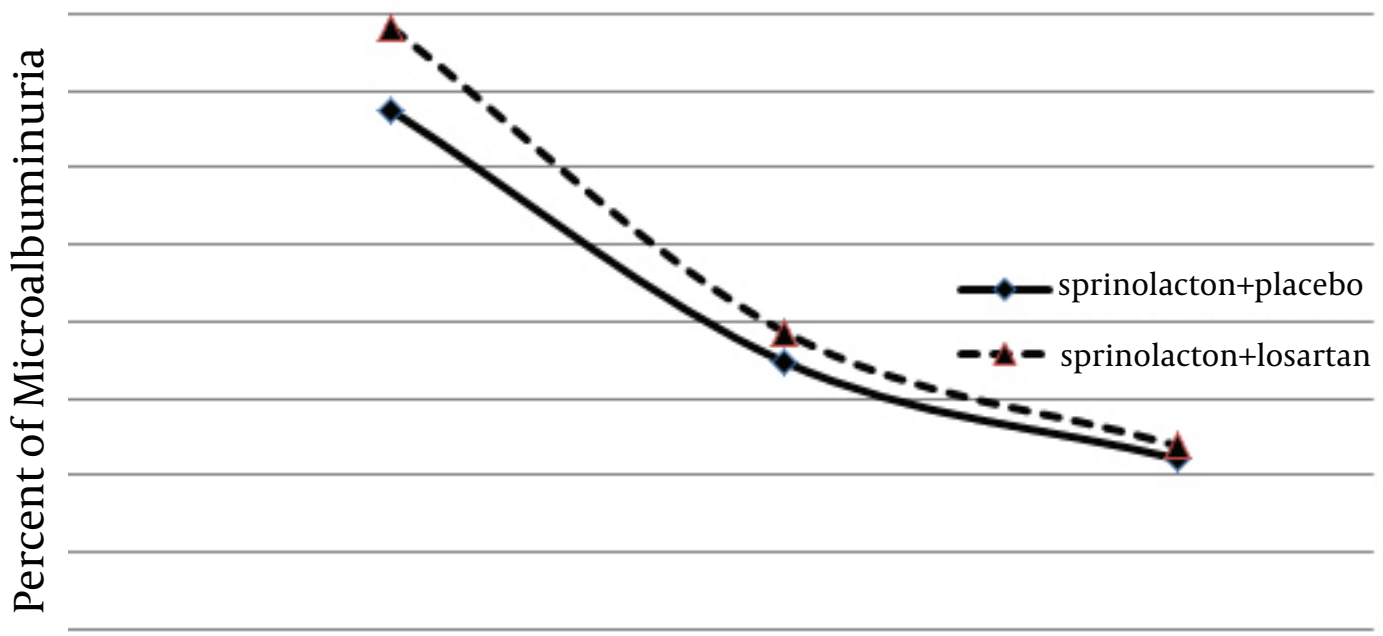

Time

Figure 1. The Trend of Treatment Response in Two Groups of Spironolacton + Losartan and Spironolacton + Placebo 
Table 3. Comparison of Microalbuminuria, Serum Creatinine Level, Serum Potassium Level, and Systolic/Diastolic Blood Pressures Between Case and Control Groups Quantitative Data After the Treatment

\begin{tabular}{|c|c|c|c|}
\hline Variable & $\begin{array}{l}\text { Spironolacton + Losartan, } \\
\text { Mean } \pm \text { SD }\end{array}$ & $\begin{array}{l}\text { Spironolacton }+ \text { Placebo, } \\
\text { Mean } \pm \text { SD }\end{array}$ & PValue \\
\hline \multicolumn{4}{|l|}{ Urine albumin, $\mathrm{mg} / \mathrm{g}$} \\
\hline After 4 weeks & $48.25 \pm 50.05$ & $46.3 \pm 45.6$ & 0.87 \\
\hline After 3 months & $33.98 \pm 35.3$ & $32.24 \pm 38.7$ & 0.86 \\
\hline \multicolumn{4}{|l|}{ Urine albumin change, $\mathrm{mg} / \mathrm{g}$} \\
\hline After 4 weeks & $-53.9 \pm 36.0$ & $-42.8 \pm 48.7$ & 0.3 \\
\hline After 3 months & $-60.4 \pm 63.4$ & $-60.4 \pm 30.5$ & 1.00 \\
\hline \multicolumn{4}{|l|}{$\mathrm{GFR}^{\mathrm{a}}, \mathrm{mL} / \mathrm{min}$} \\
\hline After 4 weeks & $116.5 \pm 26.2$ & $108.0 \pm 17.9$ & 0.2 \\
\hline After 3 months & $115.4 \pm 24.1$ & $107.5 \pm 17.2$ & 0.2 \\
\hline \multicolumn{4}{|l|}{ GFR change, $\mathrm{mL} / \mathrm{min}$} \\
\hline After 4 weeks & $0.9 \pm 15.5$ & $-4.6 \pm 15.0$ & 0.2 \\
\hline After 3 months & $-0.3 \pm 21.0$ & $-4.5 \pm 18.6$ & 0.4 \\
\hline $\begin{array}{l}\text { Systolic BP after } 3 \text { months, mean } \pm \\
\text { SD, mmHg }\end{array}$ & $130.97 \pm 9.4$ & $129.67 \pm 9.4$ & 0.6 \\
\hline Diastolic BP after 3 months, $\mathrm{mmHg}$ & $77.97 \pm 8.4$ & $77.59 \pm 6.63$ & 0.9 \\
\hline Potassium after 3 months, meq/L & $4.39 \pm 0.34$ & $4.56 \pm 0.38$ & 0.08 \\
\hline
\end{tabular}

a Abbreviation: GFR, glomerular filtration rate.

\section{Discussion}

In this study, we found that in diabetic patients, treatment with spironolactone alone has the same effect as combination therapy with spironolactone and losartan on microalbuminuria reduction. ACEIs and ARBs effectively reduce proteinuria and postpone renal disease progression in diabetic and non-diabetic patients (21, 24). Anti-proteinuria effects of ACEIs and ARBs decrease in long-term follow-ups due to the aldosterone escape phenomenon, emerged in about half of diabetic patients (14). Clinical and experimental evidences show that aldosterone can cause nephrosclerosis progression and renal fibrosis in patients with diabetes and hypertension $(2,9$, $12,14)$. ACEIs and ARBs failure in long term suppression of aldosterone is the main cause of their defeat in proteinuria management $(1,14,25)$. So the blockage of mineralocorticoid receptors with spironolactone can prevent kidney and heart damages (26). The exact mechanism of antiproteinuria effect of spironolactone is not clearly recognized. Although spironolactone is a diuretic drug, the blood pressure of patients in this study did not significantly change after the treatment, so it seems that its blocking effect on the mineralocorticoid receptors is distinct from its hemodynamic impact. In the present case, antiproteinuria effect of spironolactone was seen after 4 weeks of treatment without changes in the blood pressure. Similar findings were also reported in other studies. Effect of spironolactone in overt diabetic nephropathy was evaluated in a randomized, double blind crossover study. Rossing et al. enrolled 21 patients under the maximum dose of ACEI or ARB. Albuminuria was measured after 8 weeks. It was revealed that adding low-dose spironolactone has additional reno-cardiovascular protectional influences without significant side effects (22). In our study, monotherapy with spironolactone showed similar clinical efficiency as combination therapy with spironolactone and losartan. Rossing et al. evaluated overt diabetic nephropathy, but we studied microalbuminuria; thus the difference may affect the response rate. Rachmani et al. compared the efficacy of spironolactone alone as well as in combination with ACEI (cilazapril). In the mentioned study which only assessed diabetic females, spironolactone alone was effective in reducing albuminuria, which was similar to our results; however, the combination of spironolactone and cilazapril was more effective than spironolactone alone in their report (21). Davidson et al. studied the effect of spironolactone and ACEI on albuminuria in 11 micro and 13 macroalbuminuria subjects. They suggested that addition of spironolactone to ACEI can result in a greater microalbuminuria reduction (27).

Type IV collagen is a component of glomerular basement membrane and mesangial matrix, production of which can be induced by aldosterone. Its urinary appearance can be a reflection of its production level (28) and it causes progressive renal fibrosis. ACEIs alone do not 
have remarkable inhibitory effects in this process (29), while spironolactone reduces the progression of renal fibrosis (18). Furthermore, it has been declared that in spite of the maximum antiproteinuria effect of ACEI, urinary excretion of TGF- $\beta 1$ (transforming growth factor) is high in these patients. TGF- $\beta 1$ is a profibrotic cytokine that stimulates the protein synthesis in the extracellular matrix (30). A study on the diabetic mice has also shown that treatment with ACEI could not prevent its high production in glomeruli (31). In comparison, spironolactone could reduce the TGF- $\beta 1$ secretion in cyclosporineinduced nephrotoxicity $(32,33)$. Therefore, it seems that mineralocorticoid receptor blockers such as spironolactone are preferred to ACEIs, for TGF- $\beta 1$ inhibiting activity.

Hyperkalemia is one of the complications of spironolactone. It is dependent on drug dosage; so low dose spironolactone can provide a safe margin (22). In our study, the potassium level was carefully monitored, and only one patient (in the spironolactone-losartan group) had a potassium level of over $5.5 \mathrm{mEq} / \mathrm{L}$ at the end of the study. Our study had some limitations. Its population was pretty small and the level of microalbuminuria was different between the two groups before the intervention, but it was not statistically significant. Also, we just evaluated microalbuminuria in diabetic patients. According to our findings, we suggest that spironolactone alone can be effective in treatment of patients with diabetic nephropathy. More studies need to be done to establish the long-term beneficial clinical effects of spironolactone alone in different stages of diabetic nephropathy.

\section{Acknowledgements}

This study was Dr. Ehsan Zaboli's postgraduate thesis and was supported by a grant from Mazandaran University of Medical Sciences.

\section{Authors' Contribution}

Atieh Makhlough: literature search, study design, data collection, data interpretation, writing the manuscript. Zahra Kashi: literature search, study design, data collection, data interpretation, writing the manuscript. Ozra Akha: data collection, data interpretation, writing the manuscript. Ehsan Zaboli: literature search, study design, data collection. Jamshid Yazdanicharati: data interpretation, writing the manuscript.

\section{Financial Disclosure}

There is no financial interest to disclose.

\section{Funding/Support}

The study was supported by Mazandaran University of Medical Sciences, Sari, Iran.

\section{References}

1. Chrysostomou A, Pedagogos E, MacGregor L, Becker GJ. Doubleblind, placebo-controlled study on the effect of the aldosterone receptor antagonist spironolactone in patients who have persistent proteinuria and are on long-term angiotensin-converting enzyme inhibitor therapy, with or without an angiotensin II receptor blocker. Clin J Am Soc Nephrol. 2006;1(2):256-62.

2. Parving HH. Diabetic nephropathy: prevention and treatment. Kidney Int. 2001;60(5):2041-55.

3. Remuzzi G, Schieppati A, Ruggenenti P. Clinical practice. Nephropathy in patients with type 2 diabetes. $N$ Engl J Med. 2002;346(15):1145-51.

4. Haffner SM. Management of dyslipidemia in adults with diabetes. Diabetes Care. 2003;26 (Suppl 1):S83-6.

5. Bhaskar L, Mahin S, Ginila R, Soundararajan P. Role of the ACE ID and PPARG P12A Polymorphisms in Genetic Susceptibility of Diabetic Nephropathy in a South Indian Population. Nephro Urol Mon. 2013;5(3):813-7.

6. Wilmer WA, Rovin BH, Hebert CJ, Rao SV, Kumor K, Hebert LA. Management of glomerular proteinuria: a commentary.J Am Soc Nephrol. 2003;14(12):3217-32.

7. Randomised placebo-controlled trial of effect of ramipril on decline in glomerular filtration rate and risk of terminal renal failure in proteinuric, non-diabetic nephropathy. The GISEN Group (Gruppo Italiano di Studi Epidemiologici in Nefrologia). Lancet. 1997;349(9069):1857-63.

8. Lewis EJ, Hunsicker LG, Bain RP, Rohde RD. The effect of angiotensin-converting-enzyme inhibition on diabetic nephropathy. The Collaborative Study Group. N Engl J Med.1993;329(20):1456-62.

9. Lewis EJ, Hunsicker LG, Clarke WR, Berl T, Pohl MA, Lewis JB, et al. Renoprotective effect of the angiotensin-receptor antagonist irbesartan in patients with nephropathy due to type 2 diabetes. N Engl J Med. 2001;345(12):851-60.

10. Maschio G, Alberti D, Janin G, Locatelli F, Mann JF, Motolese M, et al. Effect of the angiotensin-converting-enzyme inhibitor benazepril on the progression of chronic renal insufficiency. The Angiotensin-Converting-Enzyme Inhibition in Progressive Renal Insufficiency Study Group. N Engl J Med. 1996;334(15):939-45.

11. Nakao N, Yoshimura A, Morita H, Takada M, Kayano T, Ideura T. Combination treatment of angiotensin-II receptor blocker and angiotensin-converting-enzyme inhibitor in non-diabetic renal disease (COOPERATE): a randomised controlled trial. Lancet. 2003;361(9352):117-24.

12. Sato A, Hayashi K, Naruse M, Saruta T. Effectiveness of aldosterone blockade in patients with diabetic nephropathy. Hypertension. 2003;41(1):64-8.

13. Morishita Y, Kusano E. Direct Renin Inhibitor: Aliskiren in Chronic Kidney Disease. Nephro Urol Mon. 2011;5(1):668-672.

14. Schjoedt KJ, Andersen S, Rossing P, Tarnow L, Parving HH. Aldosterone escape during blockade of the renin-angiotensinaldosterone system in diabetic nephropathy is associated with enhanced decline in glomerular filtration rate. Diabetologia. 2004;47(11):1936-9.

15. Greene EL, Kren S, Hostetter TH. Role of aldosterone in the remnant kidney model in the rat. JClin Invest. 1996;98(4):1063-8.

16. Quan ZY, Walser M, Hill GS. Adrenalectomy ameliorates ablative nephropathy in the rat independently of corticosterone maintenance level. Kidney Int. 1992;41(2):326-33.

17. Hostetter TH, Rosenberg ME, Ibrahim HN, Juknevicius I. Aldosterone in progressive renal disease. Semin Nephrol.2001;21(6):573-9.

18. Otani H, Otsuka F, Inagaki K, Takeda M, Miyoshi T, Suzuki J, et al. Antagonistic effects of bone morphogenetic protein-4 and -7 on renal mesangial cell proliferation induced by aldosterone through MAPK activation. Am J Physiol Renal Physiol. 2007;292(5):F1513-25.

19. Qu Y, Du E, Zhang Y, Li S, Han R, Qiu M. Changes in the Expression of Bone Morphogenetic Protein 7 and Tamm- Horsfall Protein in the Early Stages of Diabetic Nephropathy. Nephro Urol Mon. 2011;4(2):466-9.

20. Chrysostomou A, Becker G. Spironolactone in addition to ACE 
inhibition to reduce proteinuria in patients with chronic renal disease. N Engl J Med. 2001;345(12):925-6.

21. Rachmani R, Slavachevsky I, Amit M, Levi Z, Kedar Y, Berla M, et al. The effect of spironolactone, cilazapril and their combination on albuminuria in patients with hypertension and diabetic nephropathy is independent of blood pressure reduction: a randomized controlled study. Diabet Med. 2004;21(5):471-5.

22. Rossing K, Schjoedt KJ, Smidt UM, Boomsma F, Parving HH. Beneficial effects of adding spironolactone to recommended antihypertensive treatment in diabetic nephropathy: a randomized, double-masked, cross-over study. Diabetes Care. 2005;28(9):2106-12.

23. Bianchi S, Bigazzi R, Campese VM. Antagonists of aldosterone and proteinuria in patients with CKD: an uncontrolled pilot study. Am J Kidney Dis. 2005;46(1):45-51.

24. Cicoira M, Zanolla L, Rossi A, Golia G, Franceschini L, Cabrini G, et al. Failure of aldosterone suppression despite angiotensinconverting enzyme (ACE) inhibitor administration in chronic heart failure is associated with ACE DD genotype. J Am Coll Cardiol. 2001;37(7):1808-12.

25. Brenner BM, Cooper ME, de Zeeuw D, Keane WF, Mitch WE, Parving $\mathrm{HH}$, et al. Effects of losartan on renal and cardiovascular outcomes in patients with type 2 diabetes and nephropathy. $N$ Engl $J$ Med. 2001;345(12):861-9.

26. Pitt B, Remme W, Zannad F, Neaton J, Martinez F, Roniker B, et al. Eplerenone, a selective aldosterone blocker, in patients with left ventricular dysfunction after myocardial infarction. NEngl JMed.
2003;348(14):1309-21.

27. Davidson MB, Wong A, Hamrahian AH, Stevens M, Siraj ES. Effect of spironolactone therapy on albuminuria in patients with type 2 diabetes treated with angiotensin-converting enzyme inhibitors. Endocr Pract. 2008;14(8):985-92.

28. Arima S, Kohagura K, Xu HL, Sugawara A, Abe T, Satoh F, et al. Nongenomic vascular action of aldosterone in the glomerular microcirculation. J Am Soc Nephrol. 2003;14(9):2255-63.

29. Rocha R, Chander PN, Khanna K, Zuckerman A, Stier CT, Jr. Min eralocorticoid blockade reduces vascular injury in stroke-prone hypertensive rats. Hypertension. 1998;31(1 Pt 2):451-8.

30. Rossing K, Christensen PK, Jensen BR, Parving HH. Dual blockade of the renin-angiotensin system in diabetic nephropathy: a randomized double-blind crossover study. Diabetes Care. 2002;25(1):95-100.

31. Fujisawa G, Okada K, Muto S, Fujita N, Itabashi N, Kusano E, et al. Spironolactone prevents early renal injury in streptozotocininduced diabetic rats. Kidney Int. 2004;66(4):1493-502.

32. Effectiveness of spironolactone added to an angiotensin-converting enzyme inhibitor and a loop diuretic for severe chronic congestive heart failure (the Randomized Aldactone Evaluation Study [RALES]). Am J Cardiol. 1996;78(8):902-7.

33. Rossing P, Hommel E, Smidt UM, Parving HH. Reduction in albuminuria predicts a beneficial effect on diminishing the progression of human diabetic nephropathy during antihypertensive treatment. Diabetologia.1994;37(5):511-6. 